\title{
A Review on Early Age and Long-term Compressive Strength of High- volume Fly Ash Concrete
}

\author{
$\mathrm{Mu} \mathrm{Li} \mathrm{i}^{1, \mathrm{a}}$ \\ ${ }^{1}$ Beijing University of Civil Engineering and Architecture, China
}

\begin{abstract}
Fly ash is a by-product of the combustion of the coal-fired electric power stations, and disposal of fly ash has been one of the environmental challenges. Much of the studies have been focused on the mechanical property of fly ash concrete. It is no doubt that the use of high-volume fly ash as a partial replacement of cement is also one of the effect way to utilize fly ash. It is known that the compressive strength of fly ash concrete is lower than that of ordinary concrete at early age, especially for high-volume fly ash concrete. It is urgent for engineers to consider the compressive strength of high-volume fly ash concrete at different curing age. In this review, the compressive strength of high-volume fly ash concrete in various literature was reported and then analyzed. Furthermore, the proposal of the utilization of high-volume fly ash concrete is provided.
\end{abstract}

\section{Introduction}

Concrete is the most common building material around the world, and more than 10 billion tons of concrete are made each year[1]. Portland cement is the necessary component of the concrete. The manufacturing process for Portland cement is a highly energy-intensive process that emits a large amount of green-house gas[2]. The green-house gas is definitely a contributor to the greenhouse effect and global warming. Additionally, the amount of fly ash, released by factories and thermal power plants, has increased throughout the whole world, and the disposal of this large amount of fly ash has become a serious environmental challenge. The role of fly ash(FA) in the blended cement and concrete has been investigated widely in the recent years due to the benefit of reducing emission of $\mathrm{CO} 2$ and improving the performance of concrete as well as reducing the cost of construction.

High-volume fly ash(HVFA) concrete with the properties of high-performance concrete was first developed by the Canadian Centre for Mineral and Energy Technology (CANMET) in 1985[3]. High-volume fly ash concrete has emerged as useful construction material as it can consume much more fly ash than FA concrete, and HVFA concrete is also defined as concrete which contains $50 \%$ or more than $50 \%$ fly ash by weight of total binder materials $[4,5]$. The heat of hydration of HVFA concrete is lower than that of ordinary concrete and therefore the thermal cracking of HVFA concrete is less than that of ordinary concrete. Thus, it can be used in massive concrete structure.

As manufacturing concrete and building up the structure, compressive strength of concrete is the property most valued by structure designers and constructors. Although HVFA concrete has positive effect on durability of concrete[6-10], the compressive strength of HVFA concrete is lower than that of ordinary concrete at early age, the difference between the long-term compressive strength of HVFA concrete and ordinary concrete is still needed to be considered. In this review, the compressive strength of HVFA concrete is analyzed with previous literatures in order to utilize HVFA concrete better in the practical engineering.

\section{Fly ash}

According to American Society for Testing and Materials ASTM-C618[11], FA is classified into two sorts: Class F and Class C, where Class F fly ash has pozzolanic properties, Class $\mathrm{C}$ fly ash has pozzolanic properties and also some cementitious properties. The $\mathrm{CaO}$ content of Class F FA is nearly equal to $10 \%$ or less than $15 \%$, in the meantime, the $\mathrm{CaO}$ content of Class $\mathrm{C}$ FA ranges from $15 \%$ to $40 \%$ [12]. Low-calcium FA (Class F) reacts slowly compared with high-calcium FA (Class C). Without description in this review, the default type of fly ash is Class F.

\section{Early age and long-term compressive strength}

Compressive strength development is one of the important mechanical properties of hardening concrete. It relates to the mold turnover and the construction quality of the building.

HVFA concrete with 50\% Class C FA replacement level by mass showed lower compressive strength than fly ash concrete with $25 \%$ Class C FA replacement level by mass

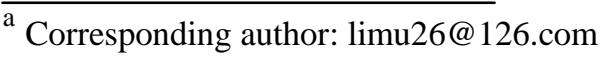


in early age, however, this trend reversed at the curing age of 90 days[13].

Rafat Siddique et al[14] found that $53.4 \%, 39.8 \%$, and $39.1 \%$ reduction in the compressive strength of concrete at curing age of 7 days, 28 days and 56 days by partially replacing cement with $50 \%$ FA, respectively, at water/binder ratio of 0.44 . The compressive strength of HVFA concrete with $50 \%$ Class C FA replacement was $22.6 \%, 21.7 \%$ and $18.3 \%$ less than that of ordinary concrete, respectively, for 3,14 and 28 days curing[15]. When the curing period is 28 days, compressive strength of HVFA concrete increased by nearly $20 \%$ as the FA content increased from $50 \%$ to $70 \%$ by mass of total cementitious materials[16]. Michelle R. Nokken et al[17] found nearly $47.6 \%$ and $85.7 \%$ reduction of compressive strength, respectively, for $60 \%$ and $80 \%$ FA replacement level by mass at the curing age of 28 days. Min-Hong Zhang and Jahidul Islam[18] found that the compressive strength of HVFA concrete with $50 \%$ FA replacement level and water-binder ratio of 0.45 was $19.5 \mathrm{MPa}$, $28.1 \mathrm{MPa}, 43 \mathrm{MPa}$ and $50.2 \mathrm{MPa}$, respectively, for 3 days, 7days, 28days and 91days.

As the replacement level of Class C FA by mass is $75 \%$, the difference of compressive strength between HVFA concrete and ordinary concrete is the highest for 3 days, and the lowest for 28 days at the water-binder ratio of 0.4[19]. Faiz U.A. Shaikh and Steve W.M. Supit[20] found that the difference of compressive strength between HVFA concrete with $60 \%$ FA replacement level and ordinary concrete is the lowest for 7 days compared with the experimental values of 3 days, 28 days, 56 days and 90 days at the water-binder ratio of 0.4 . For $50 \%$ FA replacement level, this difference is the highest for 14 days at the water-binder ratio of $0.4[21]$.

W. Chalee et al[22] found that the difference of compressive strength between HVFA concrete with $50 \%$ FA replacement by mass and ordinary concrete is the lowest for the water-binder ratio of 0.65 at the curing age of 28 days among the water-binder ratio of $0.45,0.55$ and 0.65. A. Durán-Herrera et al[23] also found the same trend that the difference of compressive strength between HVFA concrete with $60 \%$ and $75 \%$ FA replacement by mass and ordinary concrete is the lowest for the waterbinder ratio of 0.6 at the curing age of 7days, 21 days, 28 days and 56 days among the water-binder ratio of 0.5 , 0.55 and 0.6 .

C.D. Atiş[24] found a reduction in compressive strength of HVFA concrete with $50 \%$ and $70 \%$ FA replacement level by mass. The reduction in compressive strength was $53.3 \%, 17.1 \%, 22.9 \%, 6.2 \%, 7.4 \%, 2.6 \%$ and $4.8 \%$, respectively, at curing period of 1 day, 3 days, 7 days, 28 days, 3 months, 6 months and 1 year for HVFA concrete with $50 \%$ FA replacement level, while corresponding reduction was $85.4 \%, 57.4 \%, 51.3 \%, 45.3 \%, 37.3 \%$, $38.6 \%$ and $36.6 \%$ for HVFA concrete with $70 \%$ FA replacement level. It was also shown that the difference of compressive strength between HVFA concrete with $50 \%$ FA replacement level and reference concrete is only $3.4 \mathrm{MPa}$ as the curing time is 1 year.

Guðmundur Hannesson et al[25] found that the compressive strength of HVFA concrete with $60 \%$ Class $\mathrm{C}$ FA replacement level was higher than that of reference concrete at the curing age of 56 days, while the corresponding curing age was 168 days for HVFA concrete with $80 \%$ Class C FA replacement level. For Class F FA, the compressive strength of HVFA concrete with $60 \%$ Class F FA replacement level was higher than that of reference concrete at the age of 84 days, while the compressive strength of HVFA concrete with $80 \%$ Class F FA replacement level was lower than that of reference concrete at all curing ages.

Chung-Ho Huang et al[26] found that the compressive strength of HVFA concrete with $60 \%$ FA replacement level nearly approached that of reference concrete at the curing age of 91 days, while the corresponding curing age was 182 days for HVFA concrete with $80 \%$ FA replacement level. Compared with the experimental values at the curing age of 7 days, the compressive strength gain of the control concrete was less than that of HVFA concrete at the curing ages of 28 days, 56 days, 91 days, 182 days and 365 days.

Aliakbar Gholampour and Togay Ozbakkaloglu[27] replaced the high early strength cement(HESC) with ordinary Portland cement(OPC), and the main difference between HESC and OPC is the value of specific surface area(Specific surface area is $330 \mathrm{~m} 2 / \mathrm{kg}$ for OPC, while $390 \mathrm{~m} 2 / \mathrm{kg}$ for HESC.). Compared with compressive strength of HVFA concrete with 50\% FA replacement level by mass with 3 days curing, the values of compressive strength were increased by $36 \%, 156 \%$ and $203 \%$, respectively, for 7 days, 28 days and 90 days. In the same way, for HVFA concrete with $60 \%$ and $90 \%$ FA replacement level, the values of compressive strength were increased by $7 \%$ and $67 \%, 166 \%$ and $378 \%, 263 \%$ and $1089 \%$, respectively, for 7 days, 28 days and 90 days. The higher the FA replacement level was, and consequently the more compressive strength gain of HVFA concrete. Katherine Kuder et al[28] got the same trend of the compressive strength gain of HVFA concrete compared with the experimental values of 7 days, and additionally the fly ash type is Class C.

Xiao-Yong Wang and Ki-Bong Park[29] found that the compressive strength of HVFA concrete with 55\% FA replacement level might not surpass that of control concrete at later age when the ratio of water to binder is higher, but the compressive strength of HVFA concrete could be higher than that of control concrete as the water to binder ratio was lower. It could be seen that a lower water to binder ratio is more suitable for HVFA concrete. Seyoon Yoon[30] found that when the curing period is 365 days and the amount of the binder is fixed in all of the concrete mixtures $(450 \mathrm{~kg} / \mathrm{m} 3)$, the compressive strength of HVFA concrete with $50 \%$ FA replacement level is higher than that of ordinary concrete as the ratio of water to binder is 0.3 , while the trend reversed as water to binder ratios were 0.35 and 0.4 . The compressive strength of HVFA concrete with $60 \%$ fly ash was lower than that of ordinary concrete in all of the water to binder ratios $(0.3,0.35$ and 0.4$)$, and the differences of compressive strength between HVFA concrete with $60 \%$ FA replacement level and ordinary concrete were $4.2 \mathrm{MPa}$, 13.9MPa and 10.9MPa, respectively, for water to binder ratio of $0.3,0.35$ and 0.4 , in the meantime, for HVFA concrete with $50 \%$ fly ash replacement, the 
corresponding differences were -7.2MPa, 14.5MPa and 8.5MPa. Thus, it can be seen that the lower the water to binder ratio was, the lower the difference between HVFA concrete and ordinary concrete.

\section{Conclusion}

HVFA concrete has been used in the study of the concrete component[31] and the field application[32]. The application of HVFA concrete in the real structure is on the way. It is necessary for engineers to understand the influence of time-dependent effect on the compressive strength of HVFA concrete in relation to the analysis and design of concrete structures. Utilizing the long-term compressive strength of HVFA concrete is preferable for construction reality if the early age compressive strength of HVFA concrete is not emphasized in field construction. The compressive strength gain of HVFA concrete is higher than that of ordinary concrete at different curing ages. The higher the ratio of water to binder is, the lower the difference of compressive strength of HVFA concrete and ordinary concrete.

\section{References}

[1] C. Meyer, The greening of the concrete industry, Cement and Concrete Composites 31(8) (2009) 601-605.

[2] J. Yu, C. Lu, C.K.Y. Leung, G. Li, Mechanical properties of green structural concrete with ultrahighvolume fly ash, Construction and Building Materials 147 (2017) 510-518.

[3] A. Bilodeau, V.M. Malhotra, High-Volume Fly Ash System: Concrete Solution for Sustainable Development, Aci Materials Journal 97(1) (2000) págs. 41-48.

[4] P.K. Mehta, High-performance, high-volume fly ash concrete for sustainable development, 2004 Symposium on cement concrete technology and sustainable development 24 (2002).

[5] H.A. Alaka, L.O. Oyedele, High volume fly ash concrete: The practical impact of using superabundant dose of high range water reducer, Journal of Building Engineering 8 (2016) 81-90.

[6] E.G. Moffatt, M.D.A. Thomas, A. Fahim, Performance of high-volume fly ash concrete in marine environment, Cement and Concrete Research 102 (2017) 127-135.

[7] P. Jiang, L. Jiang, J. Zha, Z. Song, Influence of temperature history on chloride diffusion in high volume fly ash concrete, Construction and Building Materials 144 (2017) 677-685.

[8] O. Karahan, Transport properties of high volume fly ash or slag concrete exposed to high temperature, Construction and Building Materials 152 (2017) 898-906. [9] F.U.A. Shaikh, S.W.M. Supit, Chloride induced corrosion durability of high volume fly ash concretes containing nano particles, Construction and Building Materials 99 (2015) 208-225.

[10] P. Van den Heede, E. Gruyaert, N. De Belie, Transport properties of high-volume fly ash concrete: Capillary water sorption, water sorption under vacuum and gas permeability, Cement and Concrete Composites 32(10) (2010) 749-756.
[11] ASTM-C618, Standard Specification for Coal Fly Ash and Raw or Calcined Natural Pozzolan for Use in Concrete, ASTM International.

[12] P.J.M. Monteiro, Concrete : Microstructure, Properties, and Materials / P.K. Mehta, P.J.M. Monteiro, McGraw-Hill Professional (1993).

[13] R.U.D. Nassar, P. Soroushian, T. Ghebrab, Field investigation of high-volume fly ash pavement concrete, Resources Conservation \& Recycling 73(2) (2013) 78-85. [14] R. Siddique, K. Kapoor, E.H. Kadri, R. Bennacer, Effect of polyester fibres on the compressive strength and abrasion resistance of HVFA concrete, Construction \& Building Materials 29(4) (2012) 270-278.

[15] Y. Khodair, B. Bommareddy, Self-consolidating concrete using recycled concrete aggregate and high volume of fly ash, and slag, Construction and Building Materials 153 (2017) 307-316.

[16] I. Ignjatović, Z. Sas, J. Dragaš, J. Somlai, T. Kovács, Radiological and material characterization of high volume fly ash concrete, Journal of Environmental Radioactivity 168 (2017) 38-45.

[17] M. Nokken, Standardized Testing for Determining the Durability of High Volume Fly Ash Mixtures, Journal of Materials in Civil Engineering 97(26) (2012) 206-210. [18] M.-H. Zhang, J. Islam, Use of nano-silica to reduce setting time and increase early strength of concretes with high volumes of fly ash or slag, Construction and Building Materials 29 (2012) 573-580.

[19] Y. Khodair, M. Raza, Sustainable self-consolidating concrete using recycled asphalt pavement and high volume of supplementary cementitious materials, Construction and Building Materials 131 (2017) 245-253. [20] F.U.A. Shaikh, S.W.M. Supit, Compressive strength and durability properties of high volume fly ash (HVFA) concretes containing ultrafine fly ash (UFFA), Construction and Building Materials 82 (2015) 192-205.

[21] X. Wei, H. Zhu, G. Li, C. Zhang, L. Xiao, Properties of high volume fly ash concrete compensated by metakaolin or silica fume, Journal of Wuhan University of Technology-Mater. Sci. Ed. 22(4) (2007) 728-732.

[22] W. Chalee, P. Ausapanit, C. Jaturapitakkul, Utilization of fly ash concrete in marine environment for long term design life analysis, Materials \& Design 31(3) (2010) 1242-1249.

[23] A. Durán-Herrera, C.A. Juárez, P. Valdez, D.P. Bentz, Evaluation of sustainable high-volume fly ash concretes, Cement and Concrete Composites 33(1) (2011) $39-45$.

[24] C.D. Atiş, High-Volume Fly Ash Concrete with High Strength and Low Drying Shrinkage, Journal of Materials in Civil Engineering 15(2) (2003) 153-156.

[25] G. Hannesson, K. Kuder, R. Shogren, D. Lehman, The influence of high volume of fly ash and slag on the compressive strength of self-consolidating concrete, Construction \& Building Materials 30(30) (2012) 161168.

[26] C.-H. Huang, S.-K. Lin, C.-S. Chang, H.-J. Chen, Mix proportions and mechanical properties of concrete containing very high-volume of Class F fly ash, Construction and Building Materials 46 (2013) 71-78. 
[27] A. Gholampour, T. Ozbakkaloglu, Performance of sustainable concretes containing very high volume ClassF fly ash and ground granulated blast furnace slag, Journal of Cleaner Production 162 (2017) 1407-1417.

[28] K. Kuder, D. Lehman, J. Berman, G. Hannesson, R. Shogren, Mechanical properties of self consolidating concrete blended with high volumes of fly ash and slag, Construction \& Building Materials 34(34) (2012) 285295.

[29] X.-Y. Wang, K.-B. Park, Analysis of compressive strength development of concrete containing high volume fly ash, Construction and Building Materials 98 (2015) 810-819.

[30] S. Yoon, P.J.M. Monteiro, D.E. Macphee, F.P. Glasser, M.S.-E. Imbabi, Statistical evaluation of the mechanical properties of high-volume class $\mathrm{F}$ fly ash concretes, Construction and Building Materials 54 (2014) 432-442.

[31] S.-W. Yoo, G.-S. Ryu, J.F. Choo, Evaluation of the effects of high-volume fly ash on the flexural behavior of reinforced concrete beams, Construction and Building Materials 93 (2015) 1132-1144.

[32] M. Reiner, K. Rens, High-Volume Fly Ash Concrete: Analysis and Application, Practice Periodical on Structural Design \& Construction 11(1) (2006) 58-64. 